\title{
Minority Aspirations for Ethnically Based Territorial Autonomy in the Countries of the Carpatho-Pannonian Area since 1989
}

\author{
Károly Kocsis, Budapest*
}

with 7 figures in the text

\section{Content}

Summary

1 Introduction.

2 Minority aspirations for ethnically based territorial autonomy between 1989 and 2014 .423

3 The current geographical possibilities for ethnically based territorial autonomies

4 Conclusion..... 435

5 References.... 436

\section{Summary}

The paper presents first the autonomy aspirations of (Serbian and Hungarian) minorities during the last quarter of a century, second the geographic possibilities of ethnic-based territorial autonomy in the countries of the Carpatho-Pannonian Area (basically in Croatia, Serbia, Ukraine, Slovakia and Romania).

The territorial autonomies as the most effective tools of minority protection and the most modern forms of internal self-governance of minorities that have been created in the past decades one after the other, all over the world, do not count as novelties on the historical territory of Hungary, in the Carpathian Basin. During the years of the

* Károly Kocsis, Prof. PhD., Full member of MTA, director, Geographical Institute, Hungarian Academy of Sciences (MTA), Budaörsi út 45, H-1112 Budapest, Hungary, email: kocsis.karoly@csfk.mta.hu 
Yugoslav wars, there was a short period of territorial autonomy and independence in the case of the Serbian Krajina that sank irrecoverably into history in 1995.

After the years of the political transition, the significant Hungarian minorities of the Carpathian Basin have elaborated on their autonomy concepts that typically consist of three steps. Within these frameworks they directly articulated and frequently submitted as bills their notion of territorial self-governance, which was immediately (and in certain cases repeatedly) rejected by the Slovakian, Ukrainian, Romanian and Serbian parties.

The geographical and demographical conditions of an ethnically based territorial self-governance are available in the case of most of the settlements of Hungarian national communities in Slovakia, Transcarpathia [Zakarpattja] (Ukraine), Transylvania [Transilvania] (Romania) and Vojvodina (Serbia). It seems, however, that for the time being, due to the reasons outlined above, both short-term and medium-term political conditions are missing, even in the case of attempting to realise ethnically based associations of local self-governments (municipalities) of minorities.

\section{Introduction}

By the ethnic-linguistic diversity, the fading of the memories of the Second World War and the dissolution of the former Communist federal states from the 1960s the number and intensity of ethnic conflicts within these states has increased. In the background of the conflicts a rigid rejection of the collective rights of minorities (including those related to autonomy) and, as a result, the secessionist ambitions of the minorities could be observed in the majority of the cases. Following the civil wars on the territories of the former Yugoslavia and the Soviet Union in the 1990s, efforts were made to settle such conflicts peacefully, via negotiations, moreover, in the case of certain Western nation states that had earlier been strictly centralised, a decentralisation, and a movement towards regional self-governance could be observed (BENEDIKTER 2009). From among the states possessing solid democratic traditions, acknowledging territorial and cultural heterogeneity seeking to avoid conflict, primarily Italy, Spain, Belgium and the United Kingdom pursued the deepening of the various forms of regional power-sharing, the most common one of which, along with the system of federal and associated statehood, is autonomy.

"A territorial autonomy is a geographically defined area, which differs from other sub-regions (like municipalities, federal states, etc.) in a specific country and has received special status with legislative and/or regulatory (administrative) powers." (ACKRÉn 2009) In the past such form of autonomy was considered to be the first step towards separation, a means to disintegrate existing states (PAN \& PfEIL 2003). Today, based on positive international experiences, we believe that territorial autonomy is the most developed asset of minority protection and the most modern form of internal self- 
governance, which can be considered as a compromise between the given state (the titular nation) and the national minorities. Autonomy is a fundamental human right and ensures to the minorities preservation of the territorial integrity and the intangibility of the borders to the state.

\section{Minority aspirations for ethnically based territorial autonomy between 1989 and 2014}

\subsection{Former Yugoslavia / Croatia - the Serbian minority}

A political, economic and social transition (change of regimes) began in 1989 in the former Socialist countries of Europe, in the course of which the demolition of the Communist regime was started, and the foundations of the western-type parliamentary democracies and the market economy were laid. The most important milestones of this process were the free, multiparty parliamentary elections of 1990, which brought about the success of the parties with strong national (often nationalist) rhetoric (WEILGUNI et al. 1991).

The events taking place in the countries of the former Soviet bloc, pointing in the direction of a change of regime and also fortifying each other (e.g. revolutions, multiparty elections, starting to change the political-economic system, endeavours of federal member-states to become independent) had a great impact on the political behaviour of the Yugoslav nations and nationalities. The formerly Communist circles suddenly changed their internationalist guises into national ones and started a politics aimed at 'saving the nations'. The new Croatian constitution of 1990 recognised the Croats as the only titular nation, treated the former fellow nation, the Serbs, as a national minority and did not allow them (either) to establish an ethnically based territorial autonomy (Silber \& LitTle 1995). The outraged Croatian Serbs, manipulated by Serbia, after their referendum on the issue of autonomy on 30 September 1990, proclaimed the Serbian Autonomous Oblast of Krajina (SAO Krajina) with its seat in Knin, within the territory of Croatia, belonging in those days to Yugoslavia. Along with the escalation of the Serbo-Croatian conflict into a war, the Serbs proclaimed their independence from Croatia and joined Serbia on 2 April 1991, and later, on 19 December, they proclaimed the independent Republic of Serbian Krajina (RSK) (DAKIĆ 1994). The internationally unrecognised Serbian state formation encompassed more than a quarter (approximately 15,000 square kilometres) of the territory of Croatia including not only Krajina in a narrower sense (North Dalmatia [Sijeverna Dalmacija], Lika, Kordun, Banovina/Banija) having a Serbian majority population until then, but also certain western parts of Slavonia [Slavonija] and areas along the Danube in Croatia (Baranya [Baranja], West Srijem/Srem) (BALETIĆ et al. 1994) (Fig. 1). 
Figure 1: Ethnic structure of the Pannonian areas of Croatia and the front lines (1991)

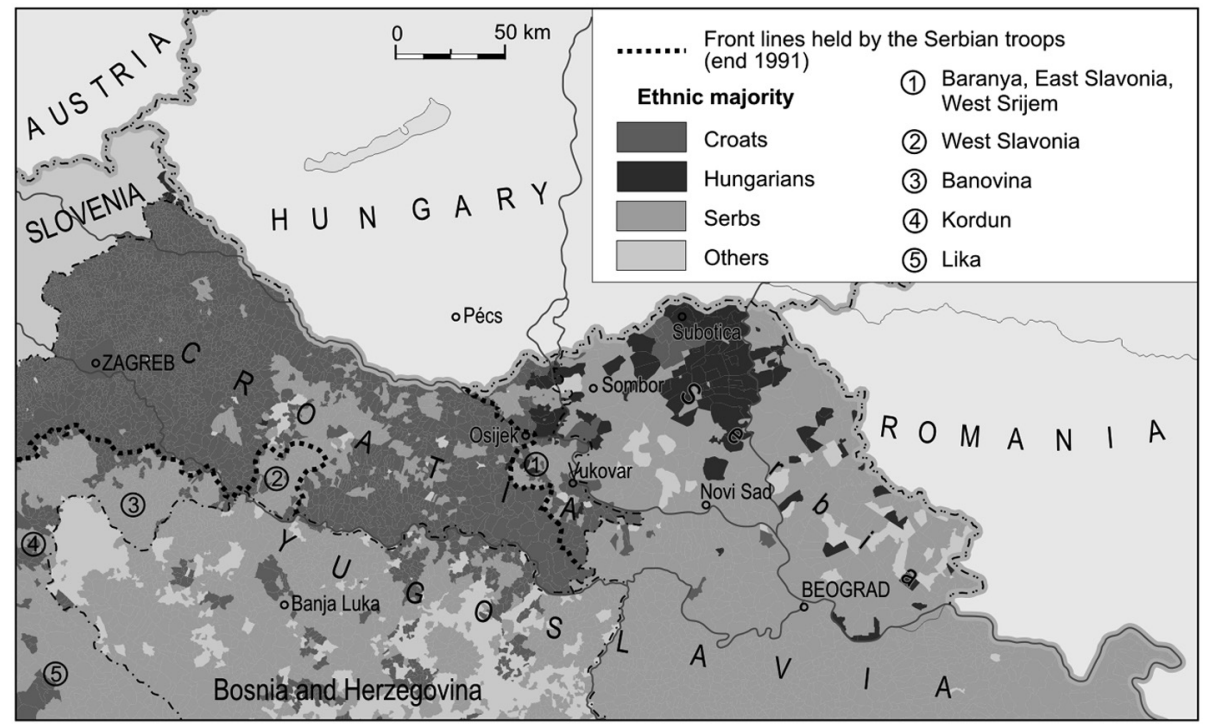

$1-5=$ Parts of the „Republic of Serbian Krajina”

As late as at the end of 1992, Croatia offered the Krajina Serbs the status of territorial autonomy (expanding to the districts [kotar] of Glina and Knin), however, since by then the Serbs had this territory in their possession, they did not find this status satisfactory. The Croatian-Serbian frontline remained basically fixed until the beginning of May 1995, when the Croatian army first re-occupied the Okučani area in West Slavonia [Zapadna Slavonija], then between 4 and 8 August the areas of North Dalmatia, Lika, Kordun and Banovina (Banija), from where more than 200,000 Serbs fled to Serbia, a small proportion of whom settled down in Baranya, East Slavonia [Istočna Slavonija] and in western Srijem (that remained under UNO-Serbian control until 1998). This put an end to the existence of the RSK and the ethnic area of the Croatian Serbs became completely decomposed because of the forced mass emigrations.

\subsection{Former Yugoslavia / Serbia - the Hungarian minority}

The Milošević regime in Serbia attempted to compensate the fact that it reduced the federal autonomies to have mere nominal statuses by 'deconcentrating' the state power in a way that in 1991 districts [okrug] governed by leaders appointed by the prime minister were created (JORDAN 2010). There were seven okrugs (districts directed from Belgrade) established in Vojvodina in a way that the Hungarian ethnic territory 
near the Tisa was subdivided into three parts (annexed to the districts of Novi Sad, Subotica and Kikinda). Incidentally, the same method was applied also with the ethnic area of the Muslims and Bosniaks in the Sanjak Region [Sandžak].

After the loss of Kosovo and the fall of Milošević, the Serbian governments gradually started to restore Vojvodina's autonomy that had been lost after 1988. The constitution of Vojvodina that has six official languages was enacted on 1 January 2010 and has been effective up to this day. Restoring the autonomy of the province that had a 2/3 Serbian majority following the 1995 mass Serbian influx also served though the interests of the Vojvodina Hungarians, who (the Democratic Fellowship of Vojvodina Hungarians, VMDK), nevertheless, had created a three-level self-governance model that includes the ethnically based territorial autonomy in 1992. The Hungarian parties forming an electoral coalition continue to have as their aim to create - along with the personal self-government - a regional self-governance for the eight Hungarianmajority municipalities [opština] near the Tisa (Hungarian Autonomous District) (GÁBRITY MolnÁR 2009). This prospective autonomous district, that would comprise almost $60 \%$ of the Vojvodina Hungarians, would have 327,000 inhabitants, out of which 53\% would be Hungarians, 24.4\% Serbs, 5.5\% Bunjevci and Croats and $8 \%$ of unknown ethnicity (2002). The territorial autonomy has not yet been established, but a wide-scope cultural (personal) autonomy was created by the Vojvodina Hungarians mainly owing to the work of the Alliance of Vojvodina Hungarians (VMSZ) (GÁBRITY MolnÁr 2009; KorHeCZ 2009, 2010).

\subsection{Former Soviet Union / Ukraine - the Hungarian minority}

The populous Hungarian minority communities established their independent (cultural and political) organisations after the fall of Communism not only in multiethnic Yugoslavia, but also on the territories of states considering themselves to be unitary nation-states, such as the present-day Ukraine, Slovakia and Romania.

Transcarpathia [Zakarpattja] was still a part of the Soviet Ukraine, when in 1989 the Hungarian Cultural Federation in Transcarpathia (KMKSZ) expressed its commitment to creating a Hungarian autonomous district with its seat in Berehovo/Beregszász (Botlik \& Dupka 1993). At the same time, the autochthonous Slavic population of the region, the Rusyns (to be more precise, the Society of Carpathian Rusyns), whose independent national existence was eliminated under Soviet supremacy, started their seemingly hopeless struggle for the restoration of the autonomy that Transcarpathia (at that time called Carpatho-Ukraine) had enjoyed in 1938/39, and this evoked extremely heated debates even locally. At the referendum held on 1 December 1991 primarily on the issue of Ukraine's independence, the vast majority of the local population in Transcarpathia supported the special self-governance status of the region (78\%), and, moreover, the foundation of the Hungarian Autonomous District in the Raion of Berehovo/Beregszász (81.4\%). All this, however, had no political consequence, since Kiev 
(pressured by nationalist forces) sternly rejected both endeavours (OSZTAPEC 2010). The unity of the young Ukrainian nation state was declared by its Constitution enacted on 28 June 1996, which was forced to acknowledge the existence of only the Autonomous Republic of Crimea [Krim] due to Russian pressure. Because of Ukraine's rejection of the ethnically based territorial autonomy, starting from 2000 the KMKSZ has initiated the formation of a Raion of the Tisa-Region with its seat in Berehovo/Beregszász, where the Hungarians would constitute the majority of the population (72\%) in a way that it would also include three quarters of the Transcarpathian Hungarians. Only a prospective future Ukrainian administrative reform would potentially allow for the changing of the district borders that had been marked in the Soviet period and that have been unaltered in the past half century, and even then on the condition that the ethnic perspectives are observed from a point of view that is favourable for Hungarians.

\subsection{Former Czechoslovakia / Slovakia - the Hungarian minority}

The Hungarian parties in Slovakia proposed several autonomy concepts and drafts in the 1990s; the earliest (in 1991) and most articulated claim for a territorial autonomy was expressed by the Coexistence-Együttélés Political Movement. These endeavours reached their summit and were devoted a wide scope national publicity at the Congress of Komárno/Komárom of the Hungarian members of Slovakian parliament and of the Hungarian mayors of Slovakia (8 January 1994) (GERENCSÉR \& JuHÁsz 2001; MolnÁR 2009). The territorial autonomy draft presented and approved depicted two scenarios (one contiguous or three Hungarian majority regions). Had the first scenario been realised, it would have resulted in creating a region of 8,245.3 square kilometres, adjacent to the Hungarian-Slovakian border, with approximately 824,000 (61.5\% Hungarian) inhabitants (Oriskó 1993; Duray et al. 1994; Kocsis 2002). The second scenario, as presented above, would have resulted in three Hungarian majority regions: 1. in the west between Bratislava (Hungarian Pozsony) and Šahy/Ipolyság (525,000 people, 63.1\% Hungarian), 2. in the middle, between Šahy/Ipolyság and Košice (Kassa) (239,000 people, 54.2\% Hungarian), 3. in the east $(59,000,77.3 \%$ Hungarian).

Both the Slovak politics and wide masses of the Slovak society reacted with plain rejection, sometimes even almost hysterically to the Hungarian plans concerning an ethnically based territorial autonomy and administrative reform (BAKKER 1997). Among the Slovaks (partly similarly to the Rusyns and Ukrainians), who had been fighting for their autonomy and independence under the Hungarian and the Czech supremacy for more than a century, the word autonomy means the endeavour to achieve an internal territorial self-governance, and equals the first milestone on the way to independence, an overt civic disloyalty and secessionism. Therefore, it did not come as a surprise that the Slovak Parliament in its Act 221/1996 on Territorial and Administrative Division enacted such - still effective - administrative order, which 
represents the exact opposite of the conceptions of the Hungarian parties. The new region [kraj] and district [okres] borders completely partitioned the Hungarian ethnic area in South Slovakia in a way that Hungarians were in minority in almost all mediumand higher-level administrative units so that the Hungarians' endeavours to achieve territorial self-governance would be prevented (KoCsis 2002; HAMBERGER 2008).

The Party of the Hungarian Coalition (MKP), that became a government party in 1998, gave up the idea of the ethnically based territorial autonomy under these new circumstances as a result of political negotiations, although initially it strove to reconsider the law of public administration referred to above. As opposed to the Coexistence-Együttélés draft mentioned above, they made vast allowances proposing the creation of a western region called "Podunajsko/Dunamente (or Komárno/Komárom)" with 602,000 inhabitants comprising a 55.2\% Hungarian majority between Šamorín/ Somorja and Šahy/Ipolyság. The plan of this Hungarian majority region was considered "professionally unfounded" and "endangering the territorial integrity of the Slovak nation state", thus it was sternly rejected by the Slovak government (as well as by the nationalist parties of the opposition). Since then the apparently hopeless issue of the Hungarian territorial autonomy has receded in the Hungarian parties' politics, and the initiative was taken over by civil motions (Comorra Aula).

\subsection{Romania - the Hungarian minority}

The Transylvanian Hungarians with more than 1.6 million at the time, founded a unified organisation for protecting their interests, called the Democratic Union of Hungarians in Romania (RMDSZ) at the end of the Romanian revolution, on 25 December 1989. By 1992, within this multi-faceted movement, a political stream articulately requesting Romania to grant minority rights, overtly demanding autonomy and relying on favourable effects of exercising pressure from abroad came into prominence, which was also reflected in requesting a fellow-nation status for the Hungarians in Romania, as well as requesting autonomy and a minority law (BÁRDI 2008). This was when the first three-step autonomy models were drafted, which included the demand for a territorial autonomy (the "Region of the Hungarian National Community" based on the free partnership of the local Hungarian-majority self-governments) (GERENCSÉR \& JuHÁsz 2001). By 1996, there were two wings within the RMDSZ, that in the meantime became a governing party: the 'moderate' wing considered the process of arriving at an autonomy to be a longer one, as opposed to the 'more radical' ('autonomist') wing. By 2003, the inner conflicts between the two wings led to the foundation of the civil organisation Hungarian National Council of Transylvania (EMNT), and with a similar goal, but primarily with the Székely Land [T,inutul Secuiesc/Székelyföld] in focus, the Székely National Council (SZNT) by the prominent figures of the 'more radical' wing. The statute of the autonomy of the Székely Land elaborated on in 2003 by the SZNT was emphatically rejected by the 
Romanian Chamber of Deputies and the Senate. The modified bill on the autonomy of the Székely Land was introduced in 2005 by the RMDSZ as a member of the government, but it was rejected by the Romanian Chamber of Deputies after a few months, and by the Senate on 25 September 2012. The bill proposed the „Székely Land Autonomous Region" to be a region encompassing 9,980 square kilometres, with a total population of 809,000 , of which $76 \%$ Hungarians. The planned autonomous region would primarily have included the today's counties of Harghita/Hargita and Covasna/Kovászna and the south-eastern part of Mureş/Maros county.

It is a little-known fact in connection with the autonomy struggles of the Transylvanian Hungarians that the EMNT supported the elaboration of a plan of a Hungarian autonomous region in Northwest Romania (Partium region) (SzILÁGYi \& CSOMORTÁNYi 2010). There have been several plans prepared for the region inhabited by a Hungarian-Romanian mixed population adjacent to the Hungarian border that has been considered by Romanians as a potential irredentist danger. The plan encompassing the largest territory would accommodate 349,000 people $(191,000$, $54.5 \%$ Hungarian and 130,000, 37.1\% Romanian) and would also include the city Satu Mare/Szatmárnémeti and towns Carei/Nagykároly/Großkarol, Şimleu Silvaniei/ Szilágysomlyó and Marghita/Margitta. This plan has not become known by the Romanian public. For the time being, the Hungarians in Northwest Romania are getting accustomed to the idea that they might achieve a territorial autonomy on their homeland.

As a consequence of the series of failures regarding plans on territorial autonomy, the RMDSZ proposed the creation of a region uniting the counties Mureş/ Maros, Harghita/Hargita and Covasna/Kovászna by restructuring the development regions planned in 1998 before the 2007 EU elections (CSUTAK 2007; SzILÁGYi 2010). This proposal for restructuring the administration of Romania was kept up until the negotiations with the president's committee of professional experts in 2010 (15 regions, one of them with a Hungarian majority).

Based on the failures of the autonomy struggles of the Hungarian minorities in Romania, Slovakia and Ukraine, it can be argued that both the titular nations and the Hungarian parties should change their approach. The Romanian, Slovakian and Ukrainian decision-makers should see the reasons and understand that a territorial autonomy is not an attack on sovereignty and does not necessarily lead to a separation, but, on the contrary, if it operates successfully, it can be a form of integration and an effective means of overcoming conflicts. Simultaneously, Hungarian minority politicians, who are at the moment seriously divided, should realise that autonomy is not a magic potion and it cannot be reached by unilateral declarations, but there should be (among others) a unity of action towards the titular nations, and at the same time, an atmosphere of trust has to be created, and all this takes a long time, patience and political wisdom (SALAT 2004). 


\section{The current geographical possibilities of ethnically based territorial autonomies in the Carpathian Basin}

Beyond the necessary political conditions, historical traditions and lucky circumstances (GHAI 2002), some ethnic and geographical-demographical conditions, as proposed above, need to be met (The minority should outnumber the titular state majority; the settlement area should be relatively contiguous and large enough as well as economically sustainable.) in order to reach ethnically based territorial autonomies (or at least regional associations of local self-governments with the minority in majority). These latter conditions are only met in the ethnic territories of the Hungarians in Slovakia, Transcarpathia, Transylvania and Vojvodina (Fig. 2). Although a century ago there used to be several hundred thousand German and Serbian minority inhabitants in the Carpathian Basin, due to the forced emigrations (of the Germans 1944-50 and the Serbs 1991-95), the territorial autonomy is no longer accomplishable for them.

Figure 2: Geographically possible ethnically based territorial autonomies in the Carpatho-Pannonian area

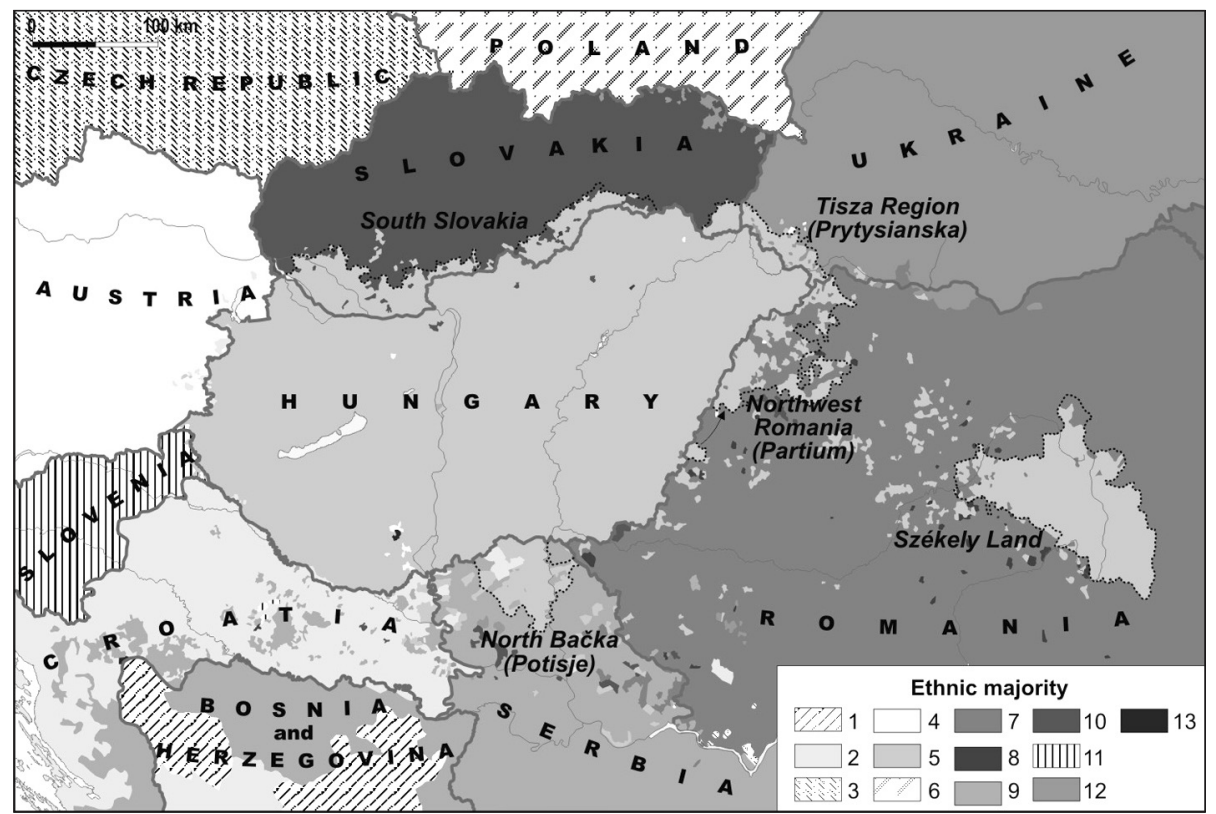

$1=$ Bosniaks, Muslims by ethnicity; 2 = Croats, Bunjevci, Šokci; $3=$ Czechs; $4=$ Germans, German-speaking Austrians; $5=$ Hungarians; $6=$ Poles; $7=$ Romanians; $8=$ Romani people; $9=$ Serbs; $10=$ Slovaks; $11=$ Slovenes; $12=$ Ukrainians; $13=$ Other ethnic groups 
During the last century on today's territory of Slovakia, the number and the proportion of people declaring Hungarian ethnicity (or mother tongue) has continuously decreased due to the forced migrations, assimilation processes and the anti-Hungarian climate of opinion connected to the building of the Czechoslovak (then, from 1993 the Slovak) nation state. In spite of this, the vast majority of the Hungarians still constitute a more or less contiguous settlement area in the southern regions of the country, near the Hungarian border, where there was a native Hungarian-speaking majority in 414 towns and villages in 2011. Since the conspicuously anti-Hungarian administrative reforms (1960, 1996), only two (Komárno/Komárom and Dunajská Streda/Dunaszerdahely) of the present 79 districts of Slovakia retained their Hungarian majority. Should natural hinterlands (catchment areas), historical traditions and ethnic relations be considered, there could be 16 districts created in Slovakia with a Hungarian-speaking majority population (Fig. 3). All the seats of these possible districts used to be district or county seats in the past century (Kocsis 2002). Out of the districts lining up near the SlovakianHungarian border, nine in the west, five in the middle and two in the east could constitute an association ("Autonomous Region of South Slovakia"), the total population of which would exceed 680,000; according to the mother tongue $63.5 \%(432,000)$ would be Hungarian, 27.9\% (190,000) Slovak, and 1.6\% (11,000) Roma. Only 15\% of the Hungarians would remain outside this imagined region, the majority of whom live in Bratislava and in the towns of the Slovakian-Hungarian linguistic boundary that used to have a Hungarian majority until 1945, and since then predominantly a Slovakian majority (Senec, Šal'a, Levice, Lučenec, Košice).

Figure 3: Share of Hungarians on the territory of the geographically possible Autonomous Region of South Slovakia (1941, 2011)

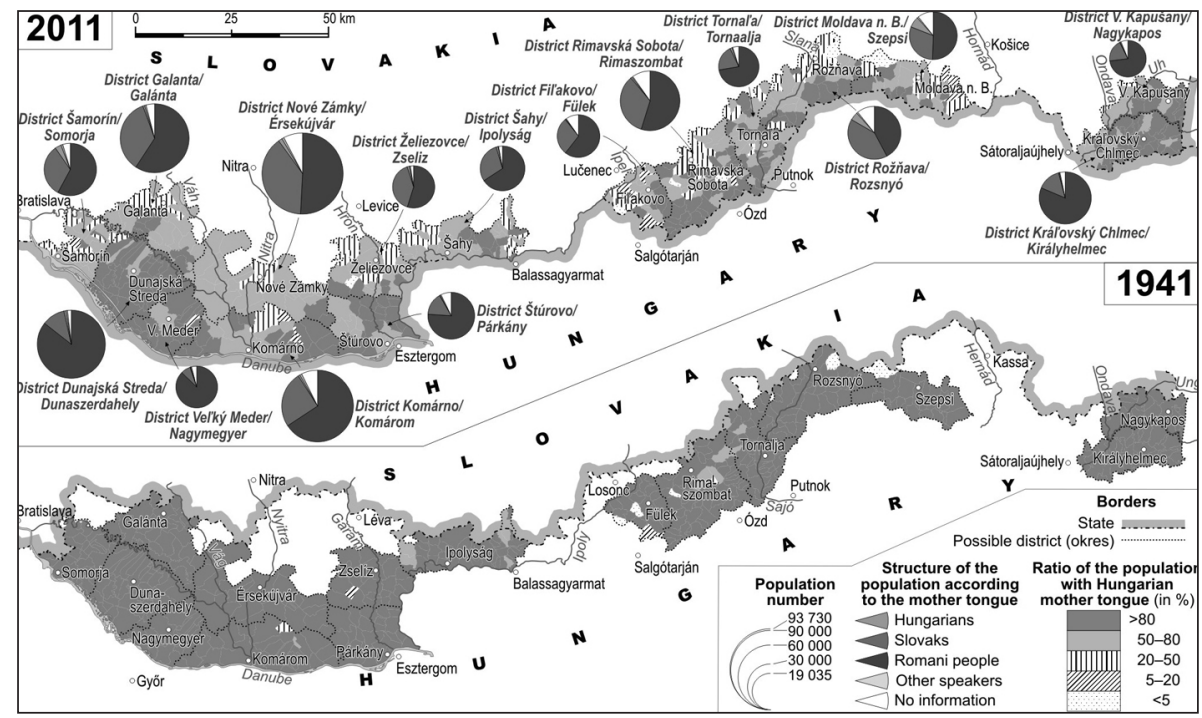


In spite of the emigrations in the past half a century, the number of Hungarians in Transcarpathia (Ukraine) has not decreased dramatically (1959: 146,000, 1979: 158,000, 2001: 152,000). Out of the 13 raions of the region there is a Hungarian majority in the raion of Berehovo/Beregszász only, constituted by (including the town of Berehovo/ Beregszász) a mere $35.6 \%$ of the Transcarpathian Hungarians. It would be necessary to reconsider the district borders that had been unchanged for the past 60 years in a way that natural hinterlands and ethnic scenes are considered; thus in the ethnic territory of the Hungarian minority adjacent to the Hungarian-Ukrainian border it would be reasonable to detach a raion of Čop (Hungarian Csap) with 49,000 inhabitants from the actual district of Uzhhorod (Ungvár), and a raion of Vylok (Tiszaújlak) with 38,000 inhabitants from today's raion of Vynohradiv (Nagyszölös) (Fig. 4). The three new districts formed in this way would have an absolute Hungarian majority and they could join to create an association ("Autonomous District of the Tisa Region", Prytysianska), the total population of which would exceed 165,000 , with $68.2 \%$ of Hungarian, $25.5 \%$ of Ukrainian, $3.9 \%$ of Roma and $1.7 \%$ of Russian ethnicity. Only one quarter of the Transcarpathian Hungarians would remain outside these raions, especially in the towns near the Hungarian-Ukrainian linguistic boundary (Uzhhorod, Mukačevo, Vynohradiv) and in the Upper Tisa valley.

Figure 4: Share of Hungarians on the territory of the geographically possible Autonomous District of the Tisa Region (Prytysianska) in Ukraine (1941, 2001)

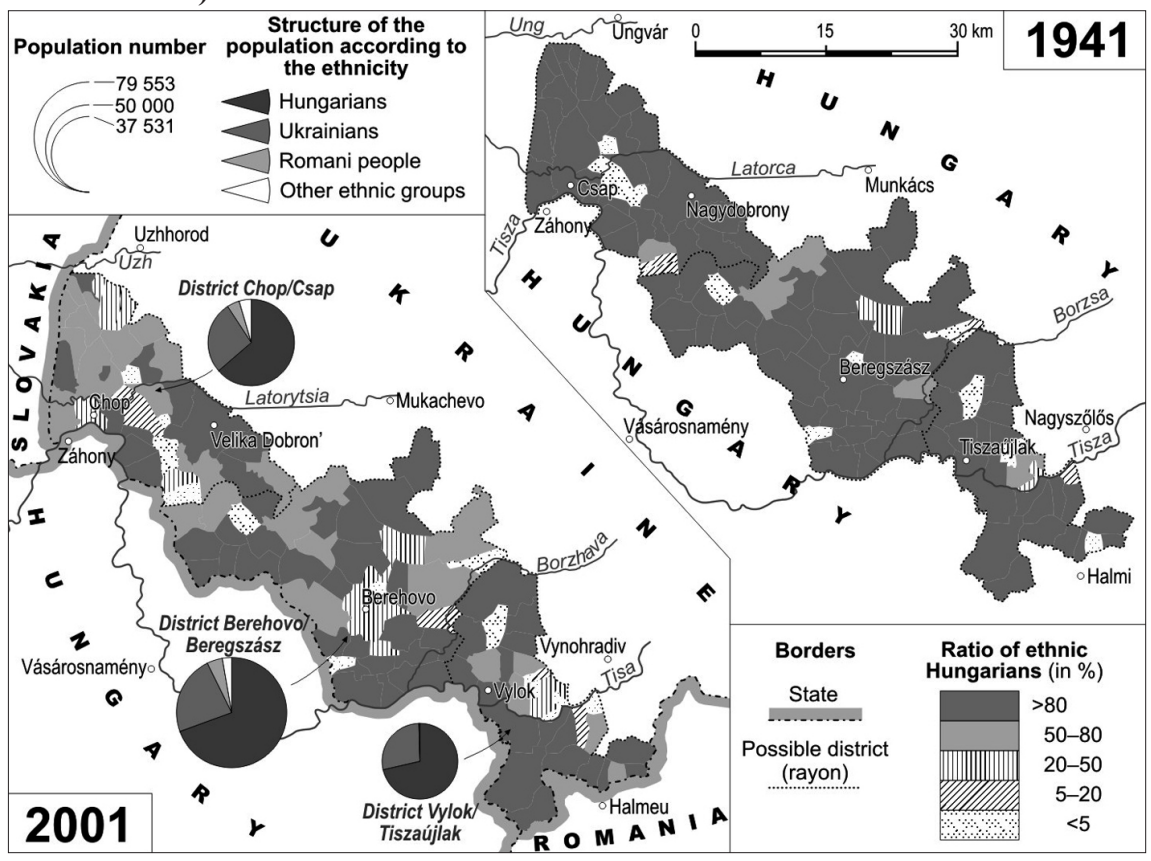


Almost all the Hungarians of Romania lived on the territories belonging to Hungary until 1918, in Transylvania [Transilvania] in the broader sense, where their number rapidly decreased in the past almost four decades - primarily because of the accelerated rate of emigration (1977: 1.7 million, 2002: 1.4 million and 2011: 1.2 million ethnic Hungarians). Presently approximately half of the Transylvanian Hungarians live in the Székely Land, almost one fifth live in Northwest Romania (Partium or Crişana-Maramureş), while one third struggles for ethnic survival in enclaves, diasporas. Since the administrative reform of 1968, out of the 16 counties of Transylvania only two, Harghita/ Hargita and Covasna/Kovászna, had a Hungarian majority. In 2011 out of the present 1,192 Transylvanian cities, towns and communes, 214 had a Hungarian majority.

From among the territories populated by minorities in the Carpathian Basin a possibility of an ethnically based territorial self-governance seems to be the most obvious in the Transylvanian Székely Land if we consider the ethnic, economic and historical background. The Hungarian (Székely) population living there enjoyed territorial autonomy from the $14^{\text {th }}$ century until 1876 (and from 1952 to 1960/68). The dominantly Hungarian ethnic nature of the historic-ethnic region called Székely Land has remained intact from the $13^{\text {th }}$ century up to recently. Without changing the boundaries of the municipalities, communes, reconsidering the catchment areas, the ethnic structure and the historical background, it would be possible to join the Hungarian-majority towns and communes of the counties of Harghita/Hargita, Covasna/Kovászna and Mureş/ Maros to create a self-governance region ("Autonomous Region of Székely Land"), which would be home to 750,000 (76.5\% Hungarian-speaking and 21.5\% Romanianspeaking) inhabitants (Fig. 5). As opposed to the historical Székely seats (Székely Land) existing until 1876, this territory would not include the Romanian-majority areas of Buzău and Becaş, Topliţa and its environs, while the adjacent Hungarian-majority communes (outside the historical Székely Land) could be incorporated.

In the north-western part of Romania, in the so-called Partium (CrişanaMaramureş) region, on the territories of the counties of Bihor, Satu Mare and Sălaj, an association of 86 (mostly Hungarian-majority) towns and communes ("Autonomous District of Partium") would be conceivable based on the catchment area of towns and the prevailing ethnic pattern, where 430,000 (56\% Hungarian-speaking, 41.1\% Romanian-speaking and $1.9 \%$ Roma-speaking) inhabitants could enjoy a territorybased self-governance (Fig. 6). This region would approximately coincide with the joint territory of the electoral districts for the Chamber of Deputies, in which a Hungarian party (RMDSZ) won the majority of the votes on 9 December 2012. One third of the Transylvanian Hungarians would remain outside the above-mentioned territories, mainly in cities (e.g. in Cluj-Napoca 49,000, Oradea/Nagyvárad 46,000, Braşov/Brassó/Kronstadt 16,000, Timişoara/Temesvár/Temesvar 15,000, Baia Mare/ Nagybánya 14,000) and in the Transylvanian basin, where an autonomy based on a local and personal principle could help to preserve their ethnic identity. 
Figure 5: Share of Hungarians on the territory of the geographically possible Autonomous Region of the Székely Land in Romania (1941, 2011)

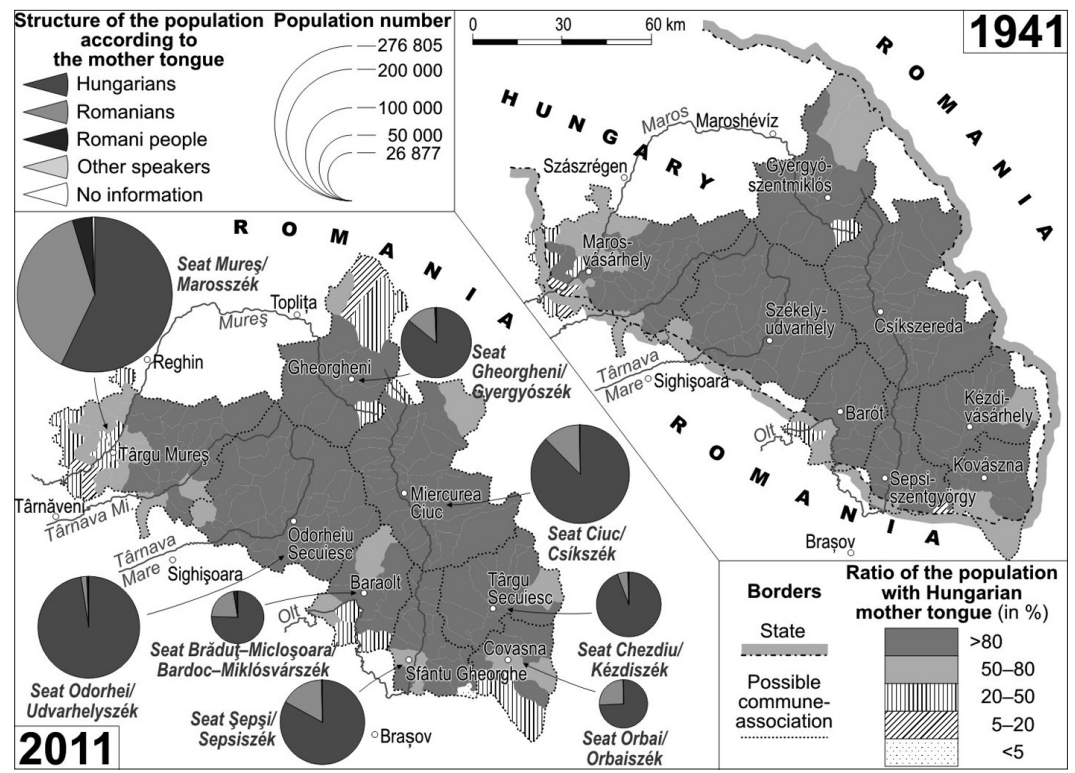

Figure 6: Share of Hungarians on the territory of the geographically possible Autonomous District of Northwest Romania (Partium) (1941, 2011)

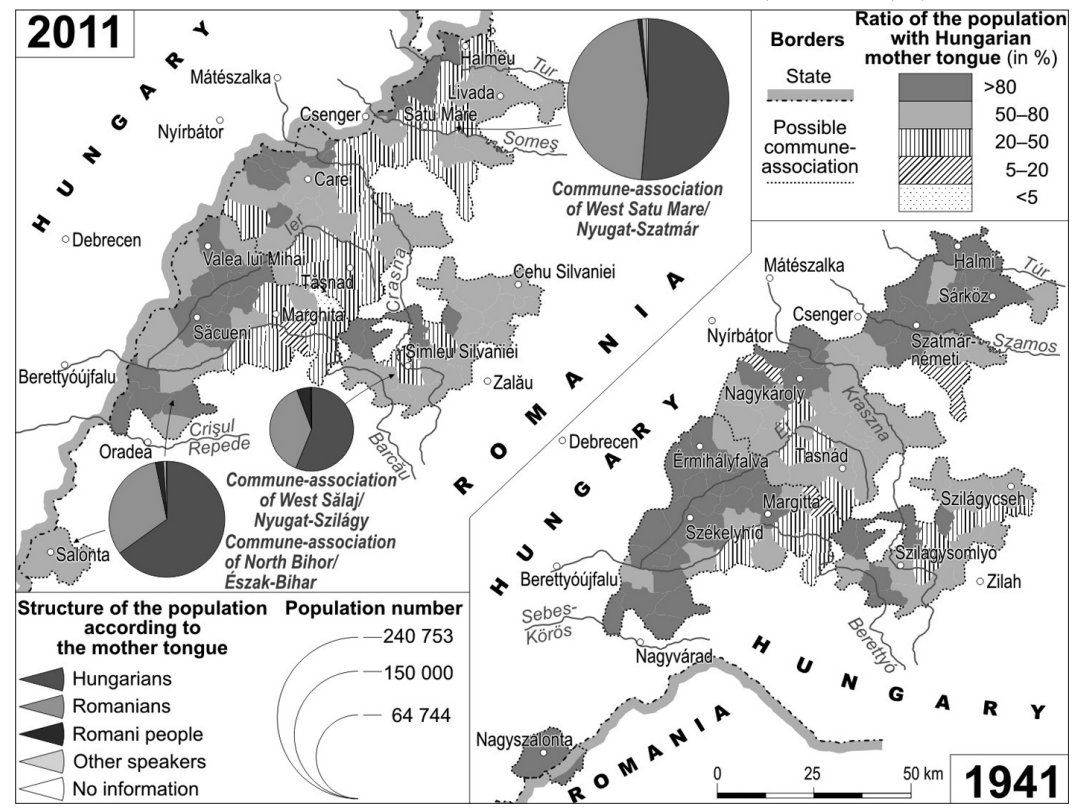


Almost all the Hungarians of Serbia (251,000 people) live on the territory of the Vojvodina Autonomous Province, where they are in majority in eight municipalities. These administrative units, located near the Hungarian-Serbian border and the Tisa, in the hinterland of the cities of Subotica/Szabadka and Senta/Zenta, could voluntarily join to form an "Autonomous District of North Bačka" with 301,000, 50.4\% of whom would be Hungarians, 25.8\% Serbs and 9.5\% Bunjevci and Croats (Fig. 7). Although $40 \%$ of the Vojvodina Hungarians (100,000 people) would remain outside this territory, their already existing cultural autonomy (based on a personal principle) and their national minority self-government organisation, the National Council of the Vojvodina Hungarians, would continue to support the preservation of their national identity.

Figure 7: Share of Hungarians on the territory of the geographically possible Autonomous District of North Bačka (Potisje) in Serbia (1941, 2011)

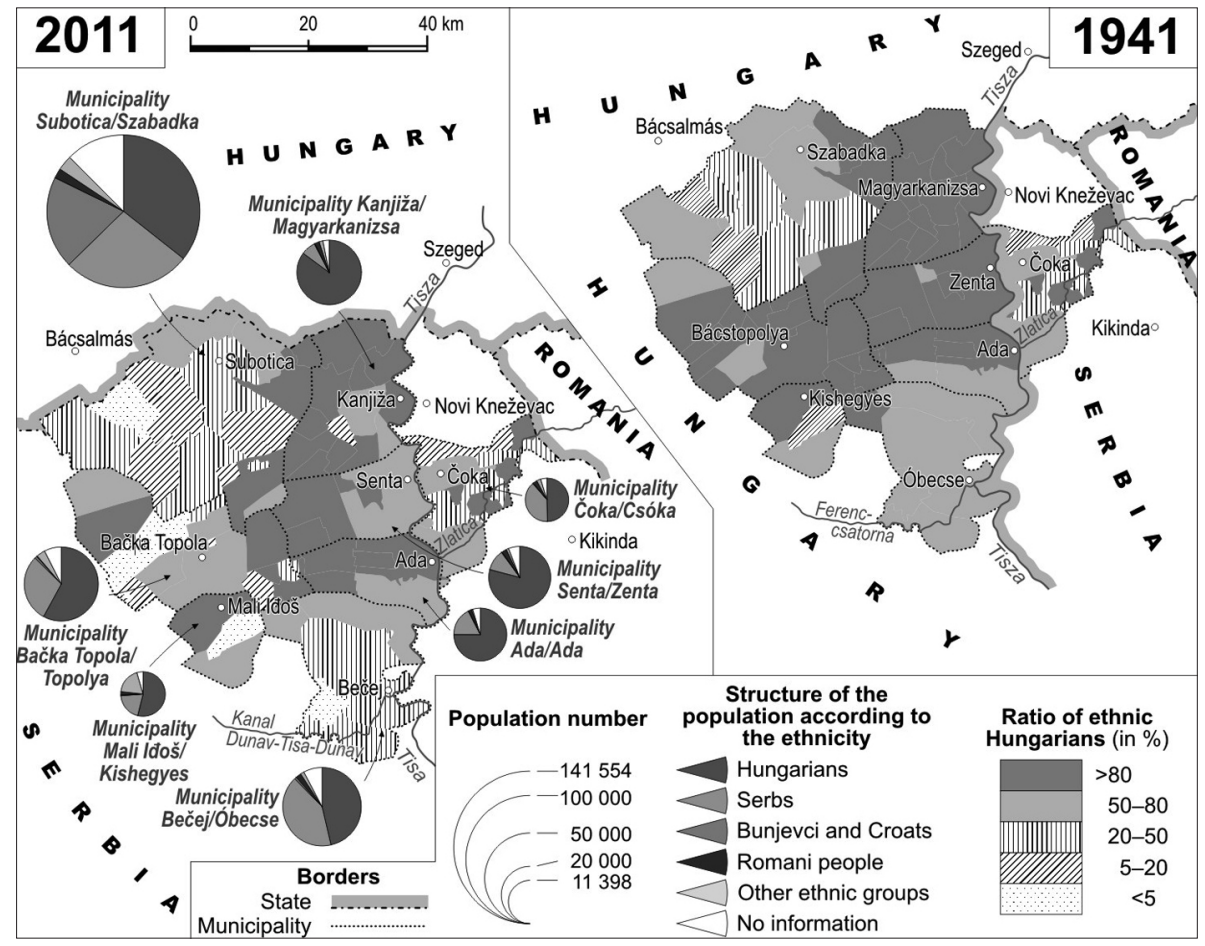




\section{Conclusion}

Territorial autonomies as the most effective tools of minority protection and the most modern forms of internal self-governance of minorities that have been created in the past decades one after the other, all over the world, do not count as novelties on the historical territory of Hungary, in the Carpathian Basin.

During the years of the Yugoslav wars, there was a short period of territorial autonomy and independence in the case of the Serbian Krajina that sank irrecoverably into history in 1995. After the years of the political transition, the significant Hungarian minorities of the Carpathian Basin have elaborated on their autonomy concepts that typically consist of three steps. Within these frameworks they directly articulated and frequently submitted as bills their notion of territorial self-governance, which was immediately (and in certain cases repeatedly) rejected by the Slovakian, Ukrainian, Romanian and Serbian parties.

Because of the shocking effects of the socio-economic systemic change (1990-) and the world economic crisis (2008-), the lack of welfare, the increasing social polarisation, the disappearance of the former strong central power, the lack of a democratic civil society, the existence of populous ethnic and national minorities and some bitter historical memories, politics frequently turns to nationalism as a weapon in the countries of the Carpathian Basin. Nationalist powers frequently provoke minorities, especially if they are large in number and live on a relatively continuous ethnic territory in order to prove that minorities mean a (mostly irredentist) danger. As a result of the economic and political difficulties, the governments in question make attempts at centralising state functions rather than at devolution of power, and they especially oppose establishing ethnically based territorial autonomies, which the titular nations conceive to be overt attacks on the territorial integrity of the state. In this respect the lessons learnt from unsuccessful examples (e.g. Kosovo, Abkhasia, Karabah, Crimea) are emphasised over successful, positive European ones.

The geographical and demographical conditions of an ethnically based territorial self-governance are available in the case of most of the settlements of Hungarian national communities in Slovakia, Transcarpathia, Transylvania (Székely Land and Partium) and Vojvodina (North Bačka). It seems, however, that for the time being, due to the reasons outlined above, both short-term and medium-term political conditions are missing, even in the case of attempting to realise ethnically based associations of local self-governments (municipalities) of minorities. 


\section{References}

Ackrén M. (2009), Conditions for Different Autonomy Regimes in the World. Åbo, Åbo Akademi University Press.

BAKKer E. (1997), Minority conflicts in Slovakia and Hungary? Capelle a/d IJssel, Labyrint Publication.

Baletić Z., Esterajher J., Jajčinović M., Klemenčić M., Milardović A., Nikić G., Višnar F. (1994), Kroatien zwischen Aggression und Frieden. Zagreb, AGM.

BÁRDI N. (2008), A romániai magyar kisebbség helyzetének változásai, társadalmi, kulturális önszerveződésének eredményei. In: BÁrdi N., Fedinec Cs., Szarka L. (eds.), Kisebbségi magyar közösségek a 20. században, pp. 330-339. Budapest, Gondolat Kiadó, MTA Kisebbségkutató Intézet.

Benedikter T. (2009), The World's Modern Autonomy Systems. Concepts and Experiences of Regional Territorial Autonomy. Bolzano, Institute of Minority Rights EURAC Research.

Bотцік J., Dupка Gy. (1993), Magyarlakta települések ezredéve Kárpátalján. Ungvár/Uzhhorod - Budapest, Intermix.

Csutak I. (2007), Új? Régi? Jó? Csíkszereda/Miercurea Ciuc, Alutus.

DAKIĆ M. (1994), The Serbian Krayina. Historical Roots and Its Birth. Knin, Iskra.

Duray M., Kvarda J., Oriskó N. (1994), A nemzetállam és demokratikus ellenszere. Pozsony/ Bratislava, Együttélés-Spolužitie.

GÁBrity Molnár I. (2009), Kisebbségi autonómia-törekvések a Vajdaságban. In: KuPA L. (ed.), Kisebbségi autonómia-törekvések Közép-Európában - a múltban és a jelenben, pp. 117129. Pécs, PTE - Bookmaster Kft.

Gerencsér B., Juhász A. (2001), A kisebbségi autonómia (működő modellek, magyar elképzelések). Budapest, Pázmány Péter Katolikus Egyetem Jog- és Államtudományi Kar.

GHAi Y. (ed.) (2002), Autonomy and Ethnicity: Negotiating Competing Claims in Multi-Ethnic States. Cambridge, Cambridge University Press.

HAMBERGER J. (2008), A magyar kisebbség jogi-politikai helyzete Szlovákiában 1989 novembere után. In: BÁrdi N., Fedinec Cs., SzArKa L. (eds.), Kisebbségi magyar közösségek a 20. században, pp. 340-345. Budapest, Gondolat Kiadó - MTA Kisebbségkutató Intézet.

Jordan P. (2010), Verwaltungsgliederung Mittel- und Südosteuropas 2007. In: Jordan P. (ed.), Atlas Ost- und Südosteuropa, 5.4-G.10. Stuttgart, Borntraeger.

Kocsis K. (2002), A közigazgatási térfelosztás változásai a mai Szlovákia területén a XX. században. In: PÁszToR C. (ed.), „Ahol a határ elválaszt” Trianon és következményei a Kárpát-medencében, pp. 131-153. Balassagyarmat, Nógrád Megyei Levéltár.

KorHecz T. (2009), Otthonteremtőben a szülöföldön. Novi Sad, Fórum.

Korhecz T. (2010), Magyar autonómia Szerbiában. A programcéltól a hatályos törvényig. In: Pro Minoritate, pp. 67-73.

Molnár M. (2009), Felvidéki magyar autonómia-törekvések. In: Kupa L. (ed.), Kisebbségi autonómia-törekvések Közép-Európában - a múltban és a jelenben, pp. 170-180. Pécs, PTE - Bookmaster Kft.

ORISKó N. (1993), Magyarok által lakott községek és városok Szlovákiában. Bratislava/Pozsony, Együttélés-Coexistence. 
Osztapec J. (2010), Politikai folyamatok Kárpátalján (1991-2009). In: Fedinec Cs., Vehes M. (eds.), Kárpátalja 1919-2009 történelem, politika, kultúra, pp. 377-392. Budapest, Argumentum, MTA Etnikai-nemzeti Kisebbségkutató Intézete.

Pan C., Pfeil B.S. (2003), National Minorities in Europe: Handbook, Vol. 1. Vienna, Braumüller ETHNOS.

Salat L. (2004), Autonómiák évadja Erdélyben. In: Krónika, VI. 6. 2004. január, pp. 10-11.

Silber L., Little A. (1995), The death of Yugoslavia. London, Penguin Books - BBC Books.

SzILÁGYI F. (2010), Az új román területi közigazgatás lehetséges elvi alapjai. In: Magyar Kisebbség, New Sery, XV, 3-4 (57-58), pp. 225-246.

SzILÁgYi F., CsOMORTÁNYI I. (2010), Önrendelkezés a Partiumban. Oradea (Nagyvárad), Partium Kiadó.

Weilguni W., Suppan A., Heuberger V., Koch K. (1991), Die Wahlen des Jahres 1990 in Mittel-, Ost- und Südosteuropa. In: Jordan P. (ed.), Atlas Ost- und Südosteuropa, 6.1-G.3. Stuttgart, Borntraeger. 